\title{
Ecological problems of modern central Kazakhstan: challenges and possible solutions
}

\author{
Turgai Alimbaev ${ }^{1}$, Zhanna Mazhitova ${ }^{2, *}$, Bibizhamal Omarova², Bekzhan Kamzayev ${ }^{2}$, and \\ Kuralai Atanakova ${ }^{3}$ \\ ${ }^{1}$ Buketov Karaganda State University, City University, 28, Karaganda, Republic of Kazakhstan \\ ${ }^{2}$ Astana Medical University, Mira Street, 49a, Nur Sultan, Republic of Kazakhstan \\ ${ }^{3}$ National University of Arts, Avenue Tauelsizdik, 50, Nur Sultan, Republic of Kazakhstan
}

\begin{abstract}
This article discusses issues related to the environmental problems in various sectors of the Central Kazakhstan's economy at the present stage. It is emphasized that the level of environmental pollution is increasing along with industrial progress in coal, non-ferrous and ferrous metallurgy, chemistry, engineering, and the growth of the transport highways network and numerous communications. The authors of the article give examples of how the transition to market mechanisms of economic development generated, on the one hand, the growth of the republic's powerful economic potential. On the other hand, the increase in industrial production with energy and resource-intensive production has led to a real threat of an environmental crisis in the region. It is concluded that the solution of the environmental problem is possible by preserving and restoring natural systems, a complete social transition to sustainable development by practical implementation of the environmental concept, including natural-resource, techno-economic, demographic and sociocultural aspects. According to the authors, these measures will contribute to the way out of the current environmental crisis, a radical improvement of the environment, will be the key to preserving the ecology of space. The methodological basis of the study was the principle of scientific objectivity, which allowed to analyze the subject under study taking into account the realities of economic changes in the industry.
\end{abstract}

\section{Introduction}

One of the important domestic policy directions in a sovereign Kazakhstan is the attempts to solve regional environmental problems of the republic [1-5]. The fact is that the development of the productive forces of Central Kazakhstan fully corresponded to the general trends of the economic development of the Republic of Kazakhstan, which is characterized by a long-term movement without taking into account the environmental characteristics of the region with increasing strain in industry proportions and socioeconomic structure. All this led to a serious aggravation of the ecological situation not only in industrial centers, but also in the entire region as a whole. At the end of the twentieth

\footnotetext{
*Corresponding author: mazhitova_69@mail.ru
} 
century, almost no city of Central Kazakhstan was not provided with drinking water of the required quality. Environmental pollution has affected the quality of food. The incidence and mortality of the population increased, especially in childhood. The industrial structure developed in Central Kazakhstan has become the main reason for a wide range of environmental problems, the nature of which, in turn, was largely determined by the activities of a specific industrial complex, their degree of impact on the quality of atmospheric air, surface and underground waters, the condition of soils, forests and other natural spheres. In this regard, at the beginning of the XXI century the inclusion of virtually all industrial centers of Central Kazakhstan into the category of the regions with alarming and difficult environmental situation was highly emblematic. It became obvious that since the time of the USSR, the Karaganda region inherited not only a powerful industrial potential, but also a difficult ecological situation, an economy with energy and resourceintensive production and outdated, polluting technologies, with the depreciation of fixed assets by $50 \%$ or more.

\section{Results and discussion}

\subsection{Statement of the problem}

In Central Kazakhstan the concentration of coal, non-ferrous and ferrous metallurgy, chemistry, mechanical engineering enterprises, the growth of the transport routes network and numerous communications, as well as the high degree of urbanization, and developed agriculture has determined a significant pollution level in all components of the environment. As a result, this region has traditionally been among the areas with the highest specific indicators for the emission of pollutants into the atmosphere and the discharge of polluted wastewater. At the same time, the most important components that determine the current general environmental situation are still the real state of the air and water basins, and the consumption of water resources. Due to the rapid development of industry and transport, air pollution, which is a vital part of the human environment, has turned into one of the most difficult environmental problems of all the time in recent decades. Despite the fact that Kazakhstan is not the main supplier of air pollutants in comparison with industrialized countries, according to the Ministry of Environment and Water Resources of the Republic of Kazakhstan at the beginning of the $21^{\text {st }}$ century the level of air pollution in cities remained quite high even with accordance with international standards [6, p. 56]. Statistics of the last decade of the twentieth century showed the emissions reduction of harmful substances into the atmosphere from stationary sources. Nevertheless, the degree of anthropogenic pressure on the natural environment of the Karaganda region remained quite high. The level of air pollution in the cities of Temirtau and Balkhash for a number of ingredients was 1.1-2.5 times higher than the average in Kazakhstan [7, p. 23]. The largest contribution to the overall indicators was made by the enterprises of the coal industry - nonferrous and ferrous metallurgy (5\%). In accordance with this, five cities with the most intense air pollution were identified in the region, i.e., Temirtau, where the chemical and metallurgical industries were concentrated, Balkhash and Dzhezkazgan - non-ferrous metallurgy, Karaganda and Shakhtinsk - coal industry, Saran - coal and chemistry. Air emissions still remain high and amount to 660 thousand tons per year or an average of 550 $\mathrm{kg}$ per inhabitant of the region. The cities of Karaganda and Temirtau still have the most polluted environment, where atmospheric emissions are: 123 thousand tons and 370 thousand tons, respectively, in some cases the content of harmful substances such as phenols and ammonia is several times higher than the maximum permissible concentrations. The most powerful pollutants remain Ispat-Karmet Karaganda metallurgical 
plant and thermal power enterprises, which account for $75 \%$ of the emissions of the region's enterprises.

In 2018, black snow was recorded in Temirtau, Karaganda Region, and therefore the atmospheric air and soil were studied by the mobile laboratory of the KazHydromet RSE. In the course of research, it was found that in the city an excess of maximum permissible concentrations (MPC) of harmful substances was recorded: ammonia up to 3.9 MPC; hydrogen sulfide up to 5 MPC; hydrocarbon up to $2.2 \mathrm{MPC}$, carbon monoxide and nitrogen dioxide up to 5 MPC. Pollution is local in nature. The source of increased concentrations of carbon and soot in black snow are enterprises of the fuel and energy complex. The analysis of samples in sediments revealed a large amount of titanium, barium, vanadium, cadmium. It also showed an increased level of iron, which indicates the contribution to the general pollution of metallurgical industry enterprises. According to the KazHydromet RSE research, the main causes of black snow are regulated emissions of industrial enterprises during periods of adverse weather conditions. Based on the Decree of the Prosecutor's Office of the Karaganda Region, the Department of Ecology of the Karaganda Region conducted an unscheduled audit of the activities of the alleged source of black snow, i.e., Arcelor Mittal Temirtau JSC. During the audit, the facts of exceeding the standards of emissions into the environment in the period from 2016-2017 and the first quarter of 2018 were established. After a series of litigations in 2019, a decision was made to recover environmental damage from Arcelor Mittal Temirtau JSC in the amount of 1.3 billion tenge. The company was also held administratively liable. The emissions of the main pollutants are given in table 1 .

Table 1. The emissions of the main pollutants.

\begin{tabular}{|c|c|c|}
\hline Industrial air emissions & $\begin{array}{c}2017 \\
\text { (thousands tons) }\end{array}$ & $\begin{array}{c}2018 \\
\text { (thousands tons) }\end{array}$ \\
\hline Sulfur Anhydride Emissions & 239.5 & 250.9 \\
\hline Nitrogen dioxide emissions & 47.8 & 48.1 \\
\hline Particulate emissions & 119.6 & 120.6 \\
\hline Carbon monoxide emissions & 168.8 & 149.0 \\
\hline & & \\
\hline
\end{tabular}

In order to attract the public to solve environmental problems in the Karaganda region in 2018, the Council on Environmental Protection was created under the chairmanship of the oblast akim (Council). The Council included representatives of non-governmental organizations, independent environmentalists, as well as heads of large industrial enterprises and government bodies. The Council is called upon to unite the efforts of the public, business, science and government bodies in making decisions in the field of ensuring safe environment and improving the ecological situation in the region [8, p. 314]. The emissions of pollutants from vehicles are of a particular concern. This is primarily due to the fact that the main highways pass through residential areas of the region's cities and the number of vehicles has increased by almost 10 times compared to 2010 . More than 200 types of harmful substances are emitted with exhaust gases, some of which have toxic and carcinogenic properties. Despite this, a number of enterprises are curtailing programs and failing to implement air protection measures that are very important for the region. Due to lack of funding, the transfer of vehicles to gas was stopped. Events such as the introduction of vehicle exhaust catalysts have been forgotten. One of the factors that have a negative impact on the ecological situation in the region is the emission of methane gas into the atmosphere.

The main thing for the protection of atmospheric air was and still remains the introduction of the latest technological processes, environmentally friendly and non-waste 
technologies and, in general, clean industries. At a number of enterprises, measures to use low-ash coals are not being implemented, which leads to an increased emission of ash into the atmosphere. However, due to the large difference in cost, high-ash coals are still widely used, especially in thermal power plants. This is just one example where the economy prevails over the environment and leads to the fact that the ecological well-being of the region and the health of the people subsequently cost more to this kind of economy [9, p. 26-34].

An important factor determining not only the environmental situation, but also the development of productive forces, at the present stage was the state of water resources. The state of water resources is of serious concern nowadays.

The huge volumes of discharged water led to special requirements for treatment facilities, the drains from which were discharged directly into water bodies. However, many urban wastewater treatment plants over the past few years have worked with significant overload. The main part of the polluted wastewater passing through them was recognized by the inspecting authorities as insufficiently treated, i.e. not appropriate to water quality. This circumstance necessitated an assessment of the sanitary condition of the region's water bodies and forecasting the population's water use, including the organization of strict control over the content of chemicals presence in water due to industrial, agricultural and domestic pollution. Small rivers and lakes were in an unfavorable condition under the influence of the intensive load from industry, communal and agricultural sectors - the number decreased, the water content decreased, the regime deteriorated, the water quality decreased, the flow of water and sediment changed, which led to shallowing and even drying out. It is significant that long-term pollution of the Nura River discharged by the Karaganda Metallurgical Plant will have a negative impact on the environment for a long time due to secondary pollution of the river with bottom sediments accumulated over previous years [10, p. 85-88]. Various organizations periodically engaged in assessing the state of water resources, their use and distribution in local areas, but there were no serious developments for concrete measures to protect groundwater for a long time.

Lake Balkhash, the third after the Caspian Sea and the drying Aral Sea, has a drainless, inland water body of the earth. The region accounts for $16 \%$ of industrial and $13 \%$ of agricultural production in Kazakhstan, more than $44 \%$ of fish catch, $75 \%$ of forage land. In addition, a non-ferrous metallurgy giant, the Balkhash smelter, is located on the lake. On the river bank Karatal operates a lead-zinc plant, exploration and development of quarries for coal, polymetallic ores are explored, and light industry enterprises operate on the basis of local raw materials. Big and direct pollutants of the lake's waters are industrial facilities of the Northern Balkhash region, which discharge wastewater through the storm sewer of numerous tailing dumps and through atmospheric air, where sulfuric anhydrite and other gases enter. For example, the Balkhash Mining and Metallurgical Combine discharges wastewater into the Tarangalyk Bay. The copper concentration in them reaches 35-48 MPC, and in case of accidental emissions exceeds 300 MPC. In recent years, observations of the hydrochemical regime of watercourses have recorded a widespread excess of sulfates over (MPC) reservoirs of fishery water use. For example, in small Sary-Shagan, the sulfate content is 7.8-8.9 times higher than the MPC, in Bertys Bay - 7.7-9.5 times, and in the Balkhash section - 7.7-8.1 times. MPC is also exceeded in the chloride content: in Maly Sary-Shagan - 1.3-1.5 times, in Bertys Bay - 1.3-1.5 times and in the Balkhash section 1.3-1.6 times. If one characterizes the pollution of Lake Balkhash as a whole, the following picture appears. Chlorides as a percentage of the total number of hydrochemical analysis exceed the maximum permissible concentration in $80.4 \%$ of cases, sulfates and copper - in $100 \%$, zinc in $25.3 \%$, fluorides in $98.0 \%$, oil products in $40 \%$, phenols in $33.3 \%$ of cases [11, p. 382]. There is a long series of microelements in the water of Lake Balkhash, among which heavy metals occupy a leading position due to the geochemical features of the soil of 
the Balkhash region, as well as their entry into rivers and the lake with wastewater and partial deposition of water from industrial objects to the surface of the reservoir. The content of manganese, copper, zinc, barium, titanium, boron, nickel, zinc and cadmium in the water of Lake Balkhash exceeds the MPC of heavy metals for fishery reservoirs. There are serious concerns about the ecology of Lake Balkhash, especially regarding the possibility of a repetition of a disaster like the Aral Sea. At the International Environmental Forum on the problems of Lake Balkhash in 2015, it was announced that Kazakhmys Corporation will complete the construction of environmentally friendly production next year, which will reduce emissions by $80-90 \%$. Over the past years, life has proved that the environmental situation in the Balkhash basin is deteriorating [12, p. 65]. Water pollution and discharges of pollutants from wastewater are given in the table 2.

Table 2. Water pollution and discharges of pollutants from wastewater.

\begin{tabular}{|c|c|c|c|}
\hline $\begin{array}{c}\text { The actual amount of } \\
\text { discharge }\end{array}$ & & 2017 & 2018 \\
\hline \multirow{2}{*}{ Industrial discharges } & The volume of wastewater million $\mathrm{m}^{3}$ & 1172,734 & 1152,516 \\
\hline & The volume of pollutants, thousand tons & 412,5 & 382 \\
\hline \multirow{2}{*}{$\begin{array}{c}\text { Domestic } \\
\text { wastewater }\end{array}$} & The volume of water disposal, mln. $\mathrm{m}^{3}$ & 152,432 & 155,567 \\
\hline & The volume of pollutants, thousand tons & 44,3 & 47 \\
\hline \multirow[t]{2}{*}{$\begin{array}{c}\text { Emergency and } \\
\text { unauthorized } \\
\text { discharges }\end{array}$} & The volume of wastewater million $\mathrm{m}^{3}$ & 2,4 & 3,1 \\
\hline & The volume of pollutants, thousand tons & 0,7569 & 3,7569 \\
\hline \multirow{2}{*}{$\begin{array}{c}\text { Total (all of the } \\
\text { above discharges) }\end{array}$} & The volume of wastewater million $\mathrm{m}^{3}$ & 1327,567 & 1311,184 \\
\hline & The volume of pollutants, thousand tons & 457,55 & 432,75 \\
\hline
\end{tabular}

The problem of the disposal of household and industrial waste has become of particular importance for large cities in the region, because for decades the process of collection, disposal and disposal of waste in most settlements did not meet the necessary sanitary and hygienic requirements.

As a result, industrial centers have turned into places of formation and accumulation of a gigantic volume of industrial and household waste, causing a critical situation at the end of the twentieth century at the landfills of almost all major cities. A significant part of them was accumulated and burned in the territories of enterprises, fell into a landfill of household waste, was arbitrarily taken to the suburban area, turning them into a hotbed of potential danger. An acute problem is the disposal of municipal solid waste in Central Kazakhstan.

The territory of the region, which possessed generally rich soil resources, also faced the phenomenon of qualitative depletion of land resources. In many areas, there has been a decline in natural fertility and land degradation. The most alarming of them is the deficit of humus, which is an organic substance of the soil, resulting from the decomposition of plant and animal residues. The agenda includes the restoration of disturbed lands that were left unowned as a result of the liquidation of a number of coal mining enterprises and which were not included in the reclaimed territories of the Karagandalikvidshaht RSGP, the reduction of the harmful effects of the Baikonur complex on the Karaganda region environment and the reduction in the area of falling areas of the separating parts of the first stages of launch vehicles (SPLV) until the complete closure of the complex. It is necessary to continue radioecological and geochemical studies on the lands adjacent to the Semipalatinsk test site of the Karkaraly district.

On October 11, 2018, an emergency occurred at the stage of the $2^{\text {nd }}$ level of the SoyuzFG launch vehicle. The place of the Soyuz-FG fall was the Karaganda region near the city 
of Zhezkazgan. At the time of the fall, $312.4 \mathrm{~kg}$ of heptyl was in the tanks of the Soyuz MS-10 Transport Manned Spacecraft (TMS). The visible strait of UDMH was about $9 \mathrm{~m}^{2}$. The volume of soil removed from the point of balloons impact was $37-39 \mathrm{~m}^{3}$.

On October 30-31, 2018, the top layer of soil from the contaminated site, together with heptyl in special containers, was transported to platform No. 90 of the Baikonur Cosmodrome. On November 11, 2018, a meeting of the working group was held on the results of work on soil detoxification at the site of the collapse of Soyuz MS-10 TMS, during which it was recommended that detoxification work be carried out at the beginning of the spring-summer period of 2019 [13, p. 314]. An alarming situation has also been created with land resources. Poor attitude to the use of land, pollution by pesticides, waterlogging of soil disturbances that contribute to the development of water and wind erosion, lead to a decrease in fertility and a reduction in useful areas. The use of highly toxic pesticides in almost all farms of the region contributes to the accumulation of persistent pesticides in soils. Most of the farms in the region do not ensure their highquality storage, they are often stored in the open air or in unsuitable premises, and the construction of typical storage facilities is extremely slow. In addition, violation of design conditions, sanitary norms and rules for the operation of gas stations, car parks, and manure depots causes great harm to the earth. The work to increase the area of green spaces in cities and regions of the region is slowly underway. To date, the area of disturbed land in the region is more than 22 thousand hectares, of which 10 thousand hectares are required to be rehabilitated. A large half of such lands is registered in coal and heat power enterprises. Existing spent quarries are used for group dumps of mine and overburden rocks, under sludge traps of concentration plants, quarries are being filled up. However, recently, due to lack of funds, there has been a sharp decline in the implementation of remediation work, both at energy enterprises and at coal enterprises. It should be noted that the Semipalatinsk nuclear test site had a negative impact on the state of land in the region, and in particular the former Egindybulak and Karkaraly districts. The results of observation on soil pollution by heavy metals are shown in table 3 .

Table 3. Concentration of metals exceeding MAC in soil samples taken in different areas of cities for spring and autumn, $\mathrm{mg} / \mathrm{m}^{3}$ for 2018.

\begin{tabular}{|c|c|c|c|}
\hline \multirow{2}{*}{ City } & Lead & Copper & Zinc \\
\cline { 2 - 4 } & \multicolumn{3}{|c|}{ Spring period } \\
\hline Balkhash & $173.1-1306.7$ & $102.4-185.4$ & $218.3-336.4$ \\
\hline Zhezkazgan & $29.4-126.4$ & $11.0-137.4$ & $42.4-428.2$ \\
\hline Karaganda & $14.2-28.7$ & $0.9-10.9$ & $12.6-26.6$ \\
\hline Temirtau & $20.2-50.8$ & $0.2-4.8$ & $14.6-37.0$ \\
\hline \multicolumn{2}{|c|}{ Autumn period } \\
\hline Balkhash & $269.5-828.4$ & $33.5-122.3$ & $135.6-331.4$ \\
\hline Zhezkazgan & $54.1-141.5$ & $10.7-32.4$ & $40.3-197.2$ \\
\hline Karaganda & $13.8-33.6$ & $1.7-4.62$ & $12.1-26.3$ \\
\hline Temirtau & $22.3-48.6$ & $0.31-2.72$ & $13.7-27.6$ \\
\hline
\end{tabular}

\subsection{Tasks and possible solutions to environmental problems in the region}

Summarizing the recommendations formulated in various legislative and executive documents, environmental and other programs for stabilizing the environmental situation in Central Kazakhstan, the following priority tasks should be highlighted: to reduce the 
harmful effects of the Baikonur complex on the environment of the Karaganda region, areas of falling separation parts of the first stages of launch vehicles (SPLV), and further complete closure of the complex. Utilization and use of mine gas methane released from liquidated coal mines of the Karaganda coal basin. It is necessary to preserve the ecosystem of Lake Balkhash. and to continue radioecological and geochemical studies on the lands adjacent to the Semipalatinsk nuclear test site of the Karkaraly region, followed by land restoration and development, and the implementation of a series of rehabilitation measures.

What measures have been taken and are being taken by environmental authorities to solve the tasks in the field of improving the environmental situation in the region? To improve work efficiency, a unified comprehensive program titled "Protection of Nature and Public Health" was reformed, which became the basis for coordination of all environmental activities in the region. Under this program, over the past 2.5 years, 2.1 billion tenge has been spent on the construction of environmental facilities, with an environmental effect of reducing atmospheric emissions by 106.2 thousand tons, and discharging insufficiently treated wastewater into surface water bodies by 69 million cubic meters. In order to create a unified system of environmental safety has tightened work on the state environmental review. The most stringent requirements are presented when considering projects of joint ventures and foreign firms. The first stage of the environmental management mechanism developed by the Department of Ecology and Bioresources and approved by the akim of the region, i.e., environmental pollution charges, played a significant role in improving the environmental performance of enterprises.

The key to preserving the environment is ecological training and education of the population in the region, thereby we want to achieve the citizens' awareness of an active, environmentally competent life position. At the same time, it is necessary to strive for "cross-cutting" environmental education. In a number of schools, vocational schools, colleges, etc. according to the educational schedule, the subject "ecology" was introduced. In some higher educational institutions, trainings of environmental specialists have started. Already this year some people underwent internships in structural units of the Ecology Department and other environmental authorities. Taking into account the need of the population for timely and objective information about the ecological state and the measures taken to improve it, all the media are used: radio, newspapers, all television channels.

\section{Conclusion}

It became apparent that the problem solution to the industrial waste was not only in reducing it, improving the technology for the disposal and disposal of waste and ensuring environmental safety, but also in creating a legal framework, including the organization and monitoring of waste; improvement and expansion of economic sanctions for the formation and misuse of industrial waste; environmental hazard assessment of waste and its location; development of waste hazard class criteria; ensuring environmental safety in the transboundary movement of hazardous waste.

At the present stage, ecology, along with economics and interethnic relations, is one of the three defining problems of the development of Kazakhstani society. The inclusion of the republic into the global civilization process, guided by the model of sustainable development, determined the need to choose a strategy for socio-economic growth that combines reasonable progress with minimizing damage to nature. Adopted in 2007, the Ecological Concept of the Republic of Kazakhstan, implementing the recommendations of the UN Conference on the Environment and Development (Rio de Janeiro, 1992) and subsequent international forums on the environment and sustainable development, emphasized that the country's sustainable development, high quality of life and health of the population, as well as national security can be ensured only if natural systems are 
maintained and the environmental quality is maintained. For this, it is necessary to formulate and consistently implement a unified state policy in the field of ecology aimed at protecting the environment and the rational use of natural resources. The conservation and restoration of natural systems should be one of the priority areas of activity of the state and society. The concept of transition to sustainable development includes a wide range of natural resource, social, techno-economic, political, environmental, demographic and sociocultural aspects of development.

\section{References}

1. G. Nyussupova, I. Rodionova, Bulletin of Geography, 16 (2011) https://doi.org/ 10.2478/v10089-011-0015-8

2. G. Nyussupova, A. Kalimurzina, Bulletin of Geography, 31, 1991-2013 (2016) https://doi.org/10.1515/bog-2016-0007

3. G. Nyussupova, A. Tokbergenova, et al., International Multidisciplinary Scientific GeoConference Surveying Geology and Mining Ecology Management, SGEM, 18 (2018) https://doi.org/10.5593/sgem2018/2.2/S08.059

4. T.A. Alimbaev, Zh.S. Mazhitova, et al., IOP Conference Series: Materials Science and Engineering, 663 (2019) https://doi.org/10.1088/1757-899X/663/1/012041

5. A. Mikolasch, M. Donath, et al., Applied Microbiology and Biotechnology, 103(1) (2019) https://doi.org/10.1007/s00253-019-10032-9

6. Current archive of the Ministry of ecology and bioresources of the Republic of Kazakhstan (2009)

7. Current archive of the Ministry of ecology and bioresources of the Republic of Kazakhstan (2009)

8. National report on the state of the environment and use of natural resources of the Republic of Kazakhstan for 2018, Astana (2019)

9. Mining journal of Kazakhstan State and prospects of the coal industry of Kazakhstan, Astana, 9 (2017)

10. M.A. Mukasheva, K.A. Nurlybayeva, A.K. Arymbekova, (International journal of applied and fundamental research, 1 (2017)

11. State report on the state of the environment of the Republic of Kazakhstan in 2009, Astana (2010)

12. Proceedings of International environmental forum on problems of lake Balkhash (Collector Balkhash, 2015)

13. National report on the state of the environment and use of natural resources of the Republic of Kazakhstan for 2018, Astana (2019) 